\title{
Detection of cognitive impairment using a machine-learning algorithm [Corrigendum]
}

Youn YC, Choi SH, Shin HW, et al. Neuropsychiatr Dis

Treat. 2018;14:2939-2945.
On page 2944, under Supplementary materials section, the correct Table S2 should read as follows:

Table S2 The TensorFlow code using CRE DOS data to predict CI

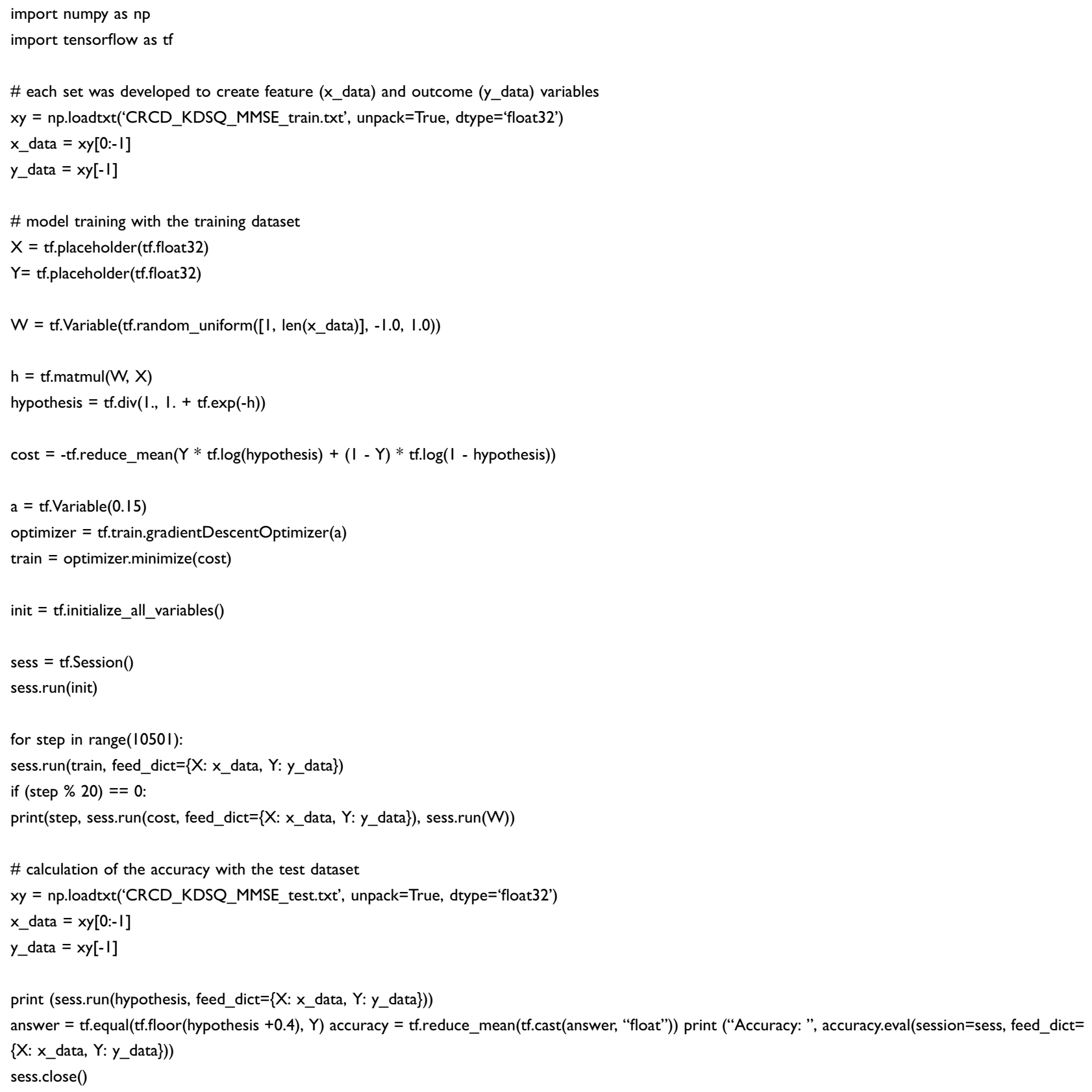

Abbreviations: $\mathrm{Cl}$, cognitive impairment; CREDOS, Clinical Research Center for Dementia of South Korea. 


\section{Publish your work in this journal}

Neuropsychiatric Disease and Treatment is an international, peerreviewed journal of clinical therapeutics and pharmacology focusing on concise rapid reporting of clinical or pre-clinical studies on a range of neuropsychiatric and neurological disorders. This journal is indexed on PubMed Central, the 'PsycINFO' database and CAS, and is the official journal of The International Neuropsychiatric Association (INA). The manuscript management system is completely online and includes a very quick and fair peer-review system, which is all easy to use. Visit http://www.dovepress.com/testimonials.php to read real quotes from published authors. 